Full-length article

\title{
Inhibition of ATP-induced calcium influx in HT4 cells by glucocorticoids: involvement of protein kinase $A^{1}$
}

\author{
Jian-zhong HAN, Wen LIN², Yi-zhang CHEN ${ }^{3}$ \\ Neuroscience Research Institute and Department of Neurobiology, ${ }^{2}$ Department of Pharmacology, College of Pharmacy, Second Military Medical \\ University, Shanghai 200433, China
}

\section{Key words}

calcium; glucocorticoids; adenosine triphosphate; protein kinase $\mathrm{C}$; protein kinase $\mathrm{A}$

\author{
${ }^{1}$ Project supported by the National Basic Re- \\ search Program of China (No G1999054003) \\ and the National Natural Science Foundation \\ of China (No 39330100 and 39840019). \\ ${ }^{3}$ Correspondence to Prof Yi-zhang CHEN \\ Phn/Fax 86-21-6534-3087. \\ E-mail yzchen@public.sta.net.cn \\ Received 2004-05-25 \\ Accepted 2004-11-19
}

doi: 10.1111/j.1745-7254.2005.00039.x

\begin{abstract}
Aim: In our previous observations, adenosine triphosphate (ATP) was found to evoke immediate elevations in intracellular free calcium concentration $\left(\left[\mathrm{Ca}^{2+}\right]_{i}\right)$ in HT4 neuroblastoma cells of mice. We tried to see if a brief pretreatment of glucocorticoids could inhibit the $\mathrm{Ca}^{2+}$ response and reveal the underlying signaling mechanism. Methods: Measurement of $\left[\mathrm{Ca}^{2+}\right]_{\mathrm{i}}$ was carried out using the dual-wavelength fluorescence method with Fura-2 as the indicator. Results: Preincubation of HT4 cells for 5 min with corticosterone (B) or bovine serum albumin conjugated corticosterone (B-BSA) inhibited the peak $\left[\mathrm{Ca}^{2+}\right]_{\mathrm{i}}$ increments in a concentration-dependent manner. Cortisol and dexamethasone had a similar action, while deoxycorticosterone and cholesterol were ineffective. Both extracellular $\mathrm{Ca}^{2+}$ influx and internal $\mathrm{Ca}^{2+}$ release contributed to ATP-induced $\left[\mathrm{Ca}^{2+}\right]_{i}$ elevation. The brief treatment with only B attenuated $\mathrm{Ca}^{2+}$ influx. Furthermore, the $\left[\mathrm{Ca}^{2+}\right]_{\mathrm{i}}$ elevation induced by the $\mathrm{P} 2 \mathrm{X}$ receptor agonist adenosine $5^{\prime}-(\beta, \gamma$-methylene) triphosphate ( $\beta, \gamma$-meATP) was also suppressed. The rapid inhibitory effect of B can be reproduced by forskolin $1 \mathrm{mmol} / \mathrm{L}$ and blocked by H89 $20 \mathrm{mmol} / \mathrm{L}$. Neither nuclear glucocorticoid receptor antagonist mifepristone nor protein kinase $\mathrm{C}$ inhibitors influenced the rapid action of B. Conclusion: Our results suggest that glucocorticoids modulate $\mathrm{P} 2 \mathrm{X}$ receptor-medicated $\mathrm{Ca}^{2+}$ influx through a membrane-initiated, non-genomic and PKA-dependent pathway in HT4 cells.
\end{abstract}

\section{Introduction}

Glucocorticoids (GC) play an important role in the developmental organization and ongoing activities of the nervous system ${ }^{[1]}$. At cellular level, they work in a diverse manner. A genomic mechanism where the complex of GC and their receptors acts as nuclear transcription factor has been well elucidated over the past 30 years, and accounts for the long-latency effects of most GC. However, some of their actions take place so rapidly (onset in seconds or minutes) that they do not fit into the paradigm of the genomic mechanism ${ }^{[2,3]}$. There are many examples in which $\mathrm{GC}$ act through the rapid, non-genomic way in the nervous system, ranging from the regulation of neuronal excitability to the modulation of neurotransmitter secretion and uptake $\mathrm{e}^{[1,2]}$.

The HT4 neuroblastoma cell line was derived from the hippocampal neurons of mice ${ }^{[4]}$. In our previous observations, we found an ATP-induced transient in $\left[\mathrm{Ca}^{2+}\right]_{\mathrm{i}}$ within the cells ${ }^{[5]}$. The $\mathrm{Ca}^{2+}$ response was decreased by the activation of protein kinase $\mathrm{A}$ (PKA) or protein kinase $\mathrm{C}$ (PKC) (unpublished data). As it is already known that some of the rapid actions of GC are mediated by protein kinases ${ }^{[6,7]}$, we wonder whether there is a similar signaling pathway for GC in HT4 cells, which may result in fast modification of the ATP-induced $\mathrm{Ca}^{2+}$ response. We provide evidence showing that ATP-induced $\mathrm{Ca}^{2+}$ response can be rapidly modified by GC through a membrane-initiated, nongenomic pathway that is PKA dependent.

\section{Materials and methods}

Materials ATP, $\beta, \gamma$-meATP, bovine serum albumin con- 
jugated corticosterone (B-BSA), cholesterol, corticosterone (B), cortisol, deoxycorticosterone, dexametha-sone, egtazic acid, $N$-[2-hydroxyethyl] piperazine- $N^{\prime}$-[2-ethanesulfonic acid] (HEPES), ionomycin, pluronic F-127, phorbol 12myristate 13-acetate (PMA), and thapsigargin (TG) were obtained from Sigma (St Louis, MO, USA). Forskolin, H89, GF-109203X, and Ro31-8220 were obtained from Calbiochem-Novabiochem (San Diego, CA). DMEM and $L$-glutamine used for cell culture from Life Technologies (Gaithersburg, MD, Germany). Trypsin from Amresco Inc (Solon, OH, USA). Fura-2 acetoxymethyl (AM) ester from Molecular Probes (Eugene, OR, USA). Newborn calf serum was from Sijiqing Co (Hangzhou, China). All other chemicals used were of analytical grade.

Cell culture HT4 cells, a kind gift from Dr B AMES (University of California at Berkeley), were maintained in DMEM containing 10\% newborn calf serum and $4 \mathrm{mmol} / \mathrm{L}$ $L$-glutamine in a humidified atmosphere of $95 \%$ air and $5 \%$ $\mathrm{CO}_{2}$ at $37^{\circ} \mathrm{C}$. No antibiotic was added to the media. For $\left[\mathrm{Ca}^{2+}\right]_{\mathrm{i}}$ measurements, cells were seeded on glass coverslips and used with in 3-4 d.

Fura-2 loading In the present study, fluorescent dye Fura-2 was used to indicate the $\left[\mathrm{Ca}^{2+}\right]_{\mathrm{i}}$. The cells on the coverslips were loaded in situ at $37^{\circ} \mathrm{C}$ for 30-60 min in HEPES-buffered saline (in mmol/L: $\mathrm{NaCl} 140, \mathrm{KCl} 5, \mathrm{MgCl}_{2}$ 1, $\mathrm{CaCl}_{2} 2.5$, glucose 11.5, HEPES 10, pH 7.2-7.4) containing Fura-2 AM $2 \mu \mathrm{mol} / \mathrm{L}$ and $0.04 \%$ pluronic F-127. The Fura-2-loaded cells were then rinsed three times with saline and mounted in a perfusion chamber for immediate $\left[\mathrm{Ca}^{2+}\right]_{\mathrm{i}}$ measurements. Alternatively, they were kept in dark conditions at room temperature for up to $2 \mathrm{~h}$. Fura-2 loading was uniform over the cytoplasm, and compartmentalization of the dye was seldom observed.

$\left[\mathrm{Ca}^{2+}\right]_{\mathbf{i}}$ measurements Measurement of $\left[\mathrm{Ca}^{2+}\right]_{\mathrm{i}}$ was carried out by the dual-wavelength fluorescence method as described previously ${ }^{[8]}$ with some modifications. Fura-2-loaded cells were mounted in a perfusion chamber and placed under an inverted microscope (IX70, Olympus). Light emitted from a 75-Wxenon arc lamp (AH2-RX, Olympus) passed through an excitation filter set (Chroma) to generate ultraviolet monochromatic waves of 340 and $380 \mathrm{~nm}$. With the aid of a computerized filter wheel (Lambda 10-2, Sutter Instruments), the cells in the chamber were alternately exposed to the two waves through an Olympus objective (UApo/340, 40× /0.90). The resulting fluorescent emission from the $\mathrm{Ca}^{2+}$-sensitive dye was collected through a $510 \mathrm{~nm}$ long pass filter (Chroma) with a cooled charge-coupled device camera (MicroMax $5 \mathrm{MHz}$ system, Princeton Instruments). All image acquisition was computer-controlled by
MetaFluor Imaging program (v.4.01, Universal Imaging Corporation). Images were acquired at 3-s intervals to reduce photobleaching. All measurements were made at $22-$ $25^{\circ} \mathrm{C}$.

Images acquired were corrected for background fluorescence and shading across the field of view. Conversion of the ratio to $\left[\mathrm{Ca}^{2+}\right]_{\mathrm{i}}$ was carried out using the equation: $\left[\mathrm{Ca}^{2+}\right]_{\mathrm{i}}$ $=K_{\mathrm{d}} \times\left[\left(R-R_{\min }\right) /\left(R_{\max }-R\right)\right] \times\left(F^{380}{ }_{\min } / F_{\max }^{380}\right)^{[8]}$, where $R_{\max }$ and $R_{\min }$ are the maximum and minimum ratio obtained by the addition of ionomycin $(10 \mu \mathrm{mol} / \mathrm{L})$ and egtazic acid (10 $\mathrm{mmol} / \mathrm{L})$ respectively, $F^{380}{ }_{\min } / F^{380}{ }_{\text {max }}$ is the ratio of $\mathrm{Ca}^{2+}$-free and $\mathrm{Ca}^{2+}$-saturated fluorescence signals at the excitation wavelength of $380 \mathrm{~nm}$, and $K_{\mathrm{d}}$ is the dissociation constant of the Fura- $2 / \mathrm{Ca}^{2+}$ complex $(224 \mathrm{nmol} / \mathrm{L}) . R$ is the acquired ratio value at each time point.

Perfusion chamber and drug applications The custom-built chamber, with a coverglass at the bottom, was continuously perfused with HEPES-buffered saline during measurements. The perfusion rate was set at $2 \mathrm{~mL} / \mathrm{min}$ to aid drug removal. All drugs were diluted in saline from their stock solutions immediately before the experiments and applied directly to the cells using a computer/manual operated 7-barrel local superfusion system for desired lengths of time. The tip (100 $\mu \mathrm{m}$ inside diameter) of the outlet was placed approximately $200 \mu \mathrm{m}$ away from the cells, and the gravity force was adjusted to achieve rapid drug application while avoiding any mechanical disturbance of the cells. The time delay for arrival of drugs at the cells was less than $100 \mathrm{~ms}$ (data not shown).

Data analysis $\left[\mathrm{Ca}^{2+}\right]_{\mathrm{i}}$ values were expressed as means \pm SD. Statistical analysis was performed using $t$-test or analysis of variance (ANOVA) depending on data types. $P<0.05$ was considered to be significant.

\section{Results}

Inhibition of ATP-induced $\left[\mathrm{Ca}^{2+}\right]_{\mathbf{i}}$ increase by GCs In HT 4 cells, the basal level of $\left[\mathrm{Ca}^{2+}\right]_{\mathrm{i}}$ was $54 \pm 8 \mathrm{nmol} / \mathrm{L}^{[5]}$. ATP $100 \mu \mathrm{mol} / \mathrm{L}$ induced an immediate rise in $\left[\mathrm{Ca}^{2+}\right]_{i}$, which was significantly attenuated by pre-incubation with $\mathrm{B}$ (1 $\mu \mathrm{mol} / \mathrm{L}$ ) for $5 \mathrm{~min}$ (Figure $1 \mathrm{~A}$ ). The original $\mathrm{Ca}^{2+}$ response recovered 5-10 min after B was washed out (data not shown). The inhibitory effect was concentration-dependent (0.1-100 $\mu \mathrm{mol} / \mathrm{L})$. B-BSA was also effective in suppressing the $\mathrm{Ca}^{2+}$ response with a similar potency compared to B (Figure 1B), while BSA had no effect on either basal or stimulated $\left[\mathrm{Ca}^{2+}\right]_{i}$ levels (data not shown). To further elucidate the rapid action of $B$, we studied the effect of mifepristone (a GR antagonist) on the response. Pretreatment with mifepristone ( $1 \mu \mathrm{mol} / \mathrm{L}$ ) for $30 \mathrm{~min}$ did not influence the inhibitory effect 

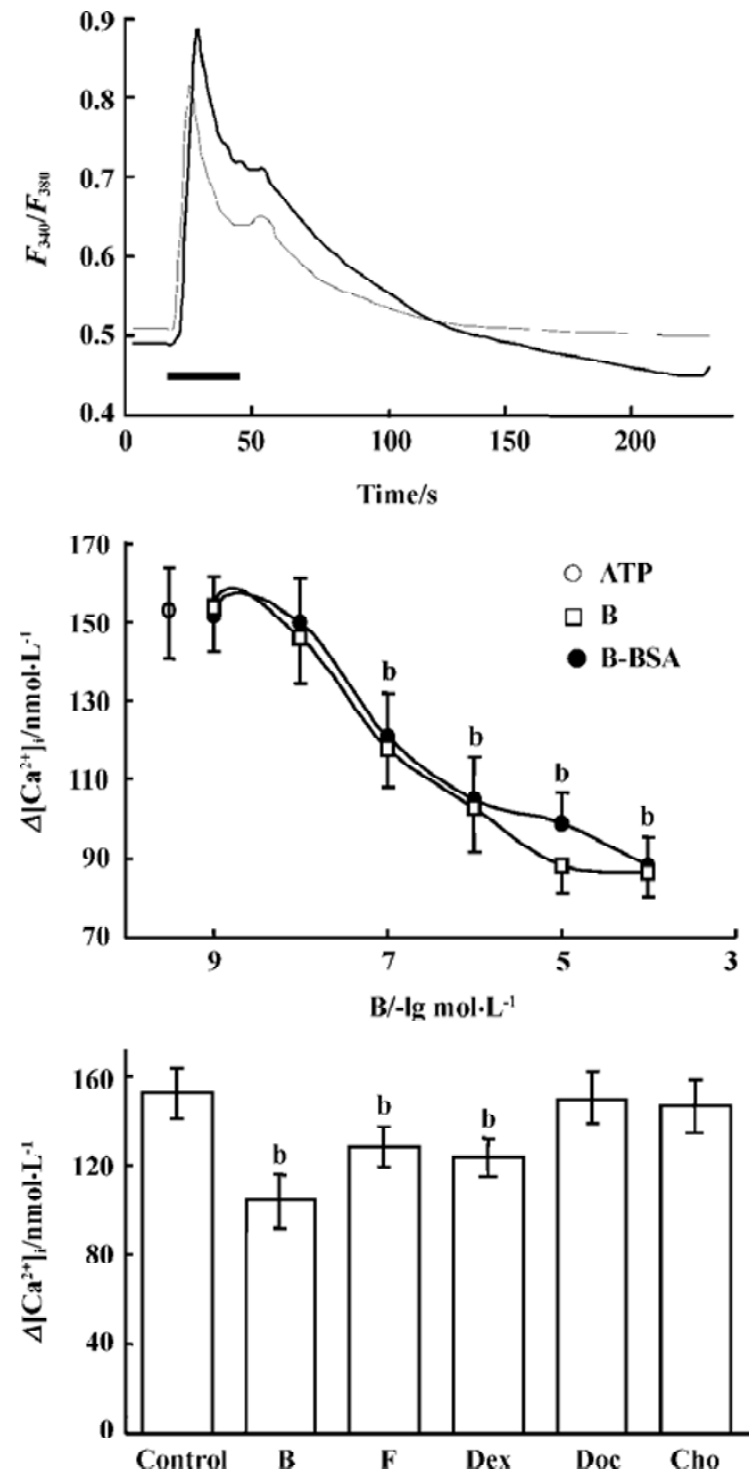

Figure 1. Inhibition of ATP-induced $\left[\mathrm{Ca}^{2+}\right]_{\mathrm{i}}$ increase by GCs in HT4 cells. (A) the $\left[\mathrm{Ca}^{2+}\right]_{\mathrm{i}}$ increase elicited by $100 \mu \mathrm{mol} / \mathrm{L}$ ATP in HEPESbuffered saline was measured after a 5 -min pre-incubation with or without $1 \mu \mathrm{mol} / \mathrm{L}$ B. Traces from representative cells are shown and superimposed for ease of comparison (continuous trace: ATP only, dotted trace: $\mathrm{B}$ pretreated). The horizontal bar represents drug application. (B) Doseresponse relationships of the $\mathrm{B}$ and $\mathrm{B}-\mathrm{BSA}$ induced inhibition. (C) $\left[\mathrm{Ca}^{2+}\right]_{\mathrm{i}}$ increases elicited by $100 \mu \mathrm{mol} / \mathrm{L}$ ATP were measured after a 5 -min preincubation with cortisol (F), dexamethasone (Dex), deoxycorticosterone (Doc), and cholesterol (Cho), respectively. All steroids were at $1 \mu \mathrm{mol} / \mathrm{L}$ in concentration. $n=3$ determinations. Mean \pm SD. ${ }^{\mathrm{b}} P<0.05$ vs control $(100$ $\mu \mathrm{mol} / \mathrm{L}$ ATP only).

of B $(1 \mu \mathrm{mol} / \mathrm{L})$ (data not shown). Thus, the findings above imply that the action of B in HT4 cells is initiated at the plasma membrane and may not involve the nuclear receptors.
Other GCs or analogs, such as cortisol and dexamethasone, were also tested and shown to be effective using the same experimental protocol. However, deoxycorticosterone and cholesterol were not effective (Figure 1C).

$\mathrm{P} 2 \mathrm{X}$ receptor-mediated $\mathrm{Ca}^{2+}$ influx was affected by $\mathrm{B}$ In the absence of extracellular $\mathrm{Ca}^{2+}$, ATP $(100 \mu \mathrm{mol} / \mathrm{L})$ was also capable of elevating $\left[\mathrm{Ca}^{2+}\right]_{\mathrm{i}}$ but with smaller amplitude. The $\left[\mathrm{Ca}^{2+}\right]_{\mathrm{i}}$ level dropped gradually to baseline even if ATP was not withdrawn. The subsequent introduction from the local superfusion system of $2.5 \mathrm{mmol} / \mathrm{L} \mathrm{Ca}^{2+}$-containing ATP solution to the same cells gave rise to a secondary calcium elevation (Figure 2A). These results suggest the generation of both $\mathrm{Ca}^{2+}$ influx across plasma membrane and $\mathrm{Ca}^{2+}$ release from intracellular stores upon ATP treatment. Using this experimental protocol, we investigated which component of the $\mathrm{Ca}^{2+}$ response was affected by the brief treatment of B. As shown in Figure $2 \mathrm{~A}$, the $\mathrm{Ca}^{2+}$ release evoked by ATP was not affected while the $\left[\mathrm{Ca}^{2+}\right]_{\mathrm{i}}$ increment during $\mathrm{Ca}^{2+}$ influx was significantly smaller after the pre-incubation of $\mathrm{B}(1 \mu \mathrm{mol} / \mathrm{L})$. $\beta, \gamma$-meATP is a specific agonist for $\mathrm{P} 2 \mathrm{X}$ receptors that has little effect on $\mathrm{P} 2 \mathrm{Y}$ receptors ${ }^{[9]}$. The $\left[\mathrm{Ca}^{2+}\right]_{\mathrm{i}}$ increase induced by $\beta, \gamma$-meATP $10 \mu \mathrm{mol} / \mathrm{L}$ in HT4 cells was also inhibited by the pre-incubation of B $(1 \mu \mathrm{mol} / \mathrm{L})$ (Figure $2 \mathrm{~B}$ and $2 \mathrm{C}$ ). Taken together, the above results suggest that $\mathrm{Ca}^{2+}$ influx through $\mathrm{P} 2 \mathrm{X}$ receptors was affected by $\mathrm{B}$.

Effect of $\mathrm{B}$ on $\mathrm{Ca}^{2+}$ influx through SOC As shown earlier, ATP increases $\mathrm{Ca}^{2+}$ release from intracellular stores in HT4 cells. The depletion of the $\mathrm{Ca}^{2+}$ stores has been reported to trigger the opening of store-operated channels (SOC $)^{[10,11]}$. We therefore examined whether B might exert its inhibitory effect by reducing $\mathrm{Ca}^{2+}$ influx through SOC. Thapsigargin (TG), a specific inhibitor of endoplasmic reticulum $\mathrm{Ca}^{2+}$-ATPase, is widely used to activate SOC by depleting $\mathrm{Ca}^{2+}$ stores. In HT4 cells, exposure of TG $(1 \mu \mathrm{mol} / \mathrm{L})$ caused an initial spike followed by a sustained elevation at lower level that was indicative of the activation of SOC. Our results showed that the TG-induced plateau was insensitive to treatment of B $(1 \mu \mathrm{mol} / \mathrm{L})$, while ATP-induced further increase in $\left[\mathrm{Ca}^{2+}\right]_{\mathrm{i}}$ at this stage was still attenuated by B (Figure 3).

Rapid action of $B$ was PKA-dependent Our previous observation found that ATP-induced $\left[\mathrm{Ca}^{2+}\right]_{\mathrm{i}}$ increase was negatively modulated by PKA or PKC in HT- 4 cells ${ }^{[5]}$. Therefore we examined whether PKA or PKC related signaling pathways were involved in the rapid action of $\mathrm{B}$. Effects of forskolin $(1 \mu \mathrm{mol} / \mathrm{L})$, PMA $(0.5 \mu \mathrm{mol} / \mathrm{L})$ on the $\left[\mathrm{Ca}^{2+}\right]_{\mathrm{i}}$ increase were studied and compared with that of $\mathrm{B}(1 \mu \mathrm{mol} / \mathrm{L})$. There was no significant difference in the degrees of inhibition among groups pretreated with forskolin or B, or both, while the effect of a combination of PMA and B was addi- 

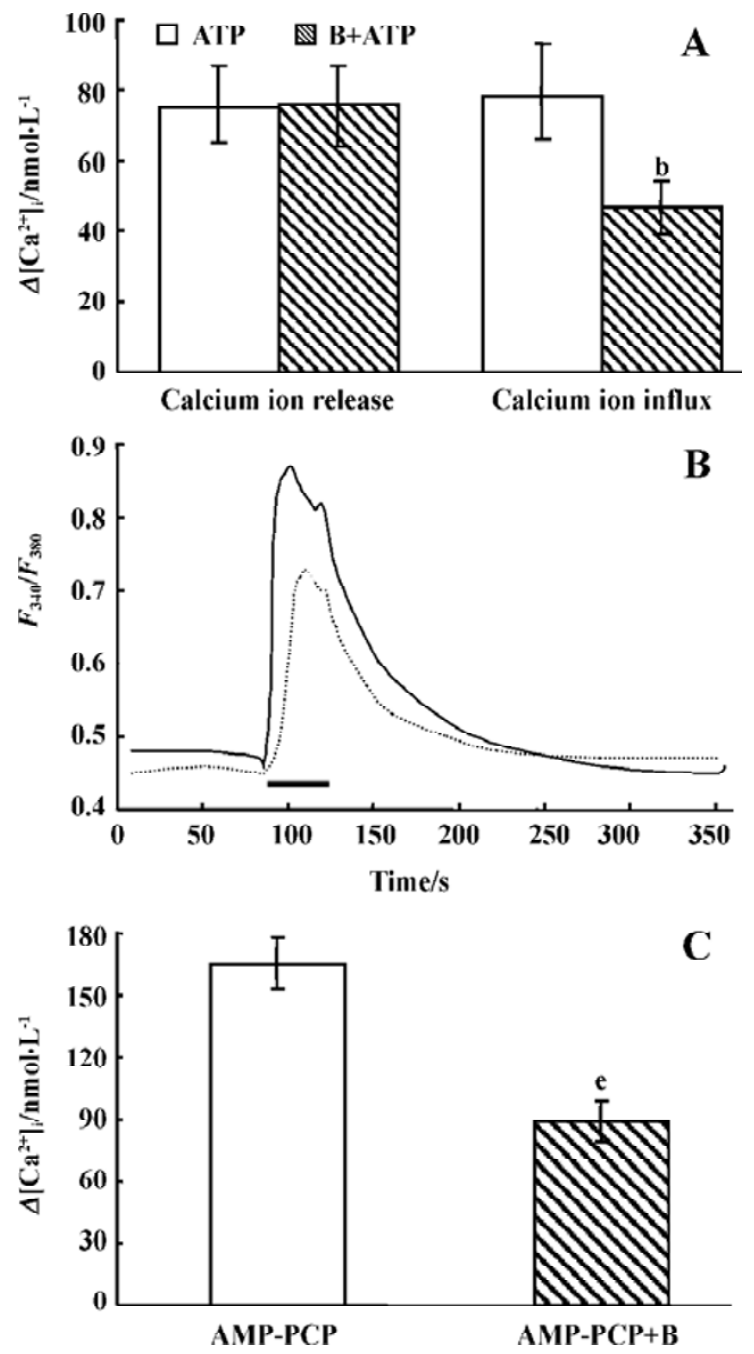

Figure 2. $\mathrm{P} 2 \mathrm{X}$ receptor-mediated $\mathrm{Ca}^{2+}$ influx was affected by B. (A) using a $\mathrm{Ca}^{2+}$-free and $\mathrm{Ca}^{2+}$-reintroduction protocol, the ATP-evoked $\mathrm{Ca}^{2+}$ influx was found to be suppressed by 5 -min pretreatment of $\mathrm{B}(1 \mu \mathrm{mol} / \mathrm{L})$. $n=3$ determinations. Mean \pm SD. ${ }^{b} P<0.05 v s$ control $(10 \mu \mathrm{mol} / \mathrm{L} \beta, \gamma$-meATP only). (B) $\beta, \gamma$-meATP $(10 \mu \mathrm{mol} / \mathrm{L})$ caused a rapid increase in $\left[\mathrm{Ca}^{2+}\right]_{\mathrm{i}}$ (continuous trace), which was inhibited by pretreatment of the cells for 5 min with $1 \mu \mathrm{mol} / \mathrm{L} \mathrm{B}$ (dotted trace). The horizontal bar represents drug application. (C) $n=3$ determinations. Mean \pm SD. ${ }^{\mathrm{e}} P<0.05$ vs AMP-PCP group.

tive (Figure 4). These results imply that the forskolin-activated pathway is involved in the signaling of B-induced inhibition. However, PMA and B exerted their modulatory effects through distinct pathways. PKA inhibitor H89 (20 $\mu \mathrm{mol} / \mathrm{L})$, when applied $20 \mathrm{~min}$ before $\mathrm{B}$, completely abrogated the inhibitory effect of B $(1 \mu \mathrm{mol} / \mathrm{L})$, while PKC inhibitors Ro31-8220 (0.5 $\mu \mathrm{mol} / \mathrm{L})$ and GF-109203X (0.5 $\mu \mathrm{mol} / \mathrm{L}$ ) had little influence (Figure 4). None of the drugs changed the basal $\left[\mathrm{Ca}^{2+}\right]_{\mathrm{i}}$ level in HT4 cells (data not shown).
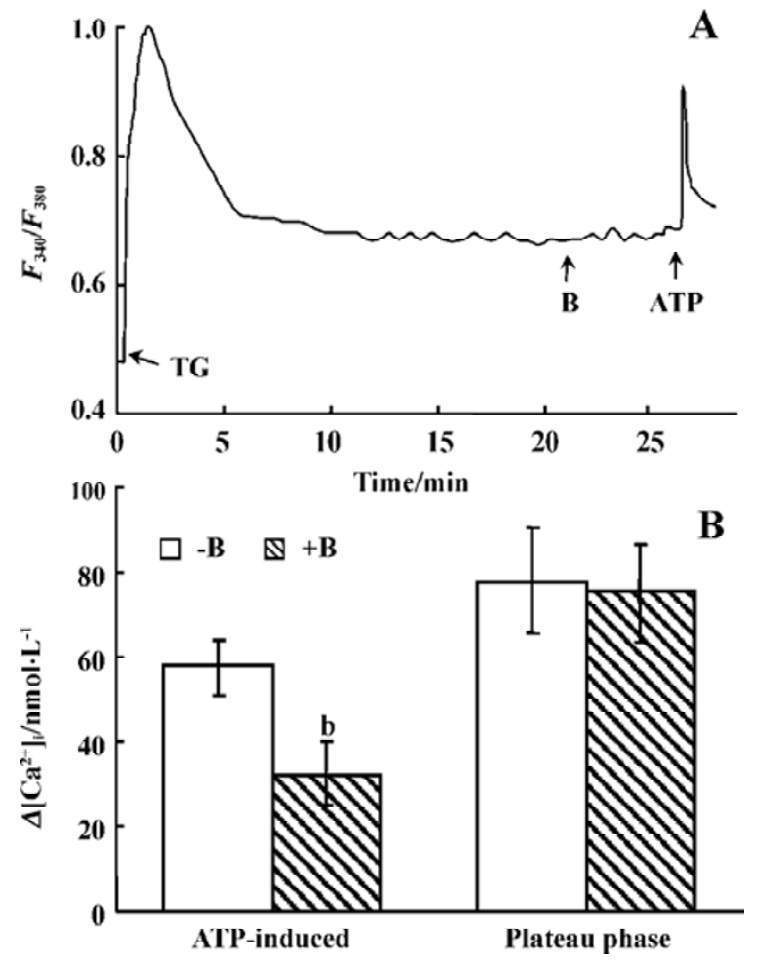

Figure 3. Effect of B on ATP-induced $\left[\mathrm{Ca}^{2+}\right]_{\mathrm{i}}$ increase after TG treatment. HT-4 cells were first exposed to TG $(1 \mu \mathrm{mol} / \mathrm{L})$ and subsequently stimulated with ATP $(100 \mu \mathrm{mol} / \mathrm{L}) 25 \mathrm{~min}$ later. B $(1 \mu \mathrm{mol} / \mathrm{L})$ was applied 20 min after TG when the $\left[\mathrm{Ca}^{2+}\right]_{\mathrm{i}}$ levels reached a plateau. (A) a representative trace is presented to show the experimental protocol. (B) $\Delta\left[\mathrm{Ca}^{2+}\right]_{\mathrm{i}}$ values recorded immediately before ATP application represents the plateau phase $\mathrm{Ca}^{2+}$ levels. $n=3-4$ determinations. Mean \pm SD. ${ }^{b} P<0.05$ vs control (100 $\mu \mathrm{mol} / \mathrm{L}$ ATP after TG treatment).

\section{Discussion}

Pre-incubation with B inhibited the ATP-induced $\left[\mathrm{Ca}^{2+}\right]_{i}$ increase in HT4 cells in a concentration-dependent manner. The minimum effective dose was $100 \mu \mathrm{mol} / \mathrm{L}$, which falls below the peak-free B concentration $(750 \mu \mathrm{mol} / \mathrm{L})$ in serum during stress ${ }^{[12]}$. The pre-incubation time for B adopted in most of our experiments was $5 \mathrm{~min}$. However, a 3-min pretreatment was found to be enough for B to take effect (data not shown). The very short latency is consistent with the criteria to define a rapid effect of steroid hormones ${ }^{[1]}$. Moreover, the rapid action was insensitive to treatment with nuclear receptor antagonist, further supporting the notion that this is a nongenomic effect of B.

Being large and predominantly hydrophilic molecules, steroid-BSA conjugates are thought to be membrane impermeable within $30 \mathrm{~min}^{[13]}$. However, they are biologically active and can reproduce the actions of free steroids ${ }^{[14]}$. In our study, B-BSA was found to be effective in inhibiting 


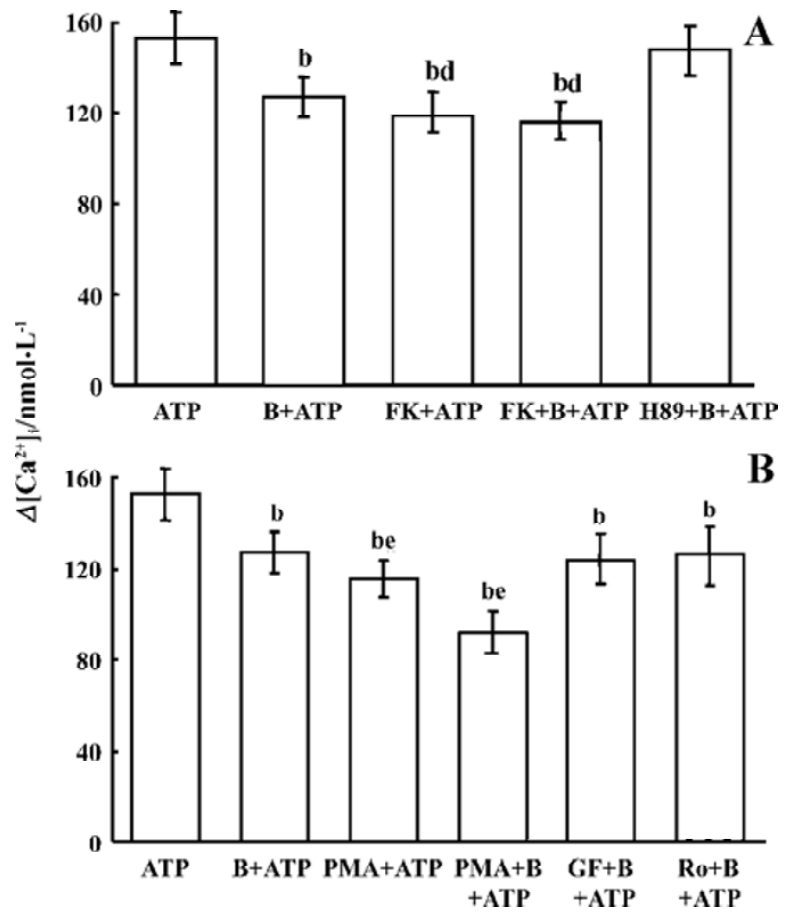

Figure 4. Rapid action of B was PKA-dependent. (A) before ATP (100 $\mu \mathrm{mol} / \mathrm{L})$ stimulation, HT4 cells were pretreated with B $(1 \mu \mathrm{mol} / \mathrm{L})$ for 5 min or forskolin (FK, $1 \mu \mathrm{mol} / \mathrm{L})$ for $10 \mathrm{~min}$ or in combination. In experiments using H89 $(20 \mu \mathrm{mol} / \mathrm{L})$, the drug was applied $20 \mathrm{~min}$ before the addition of B. (B) before ATP $(100 \mu \mathrm{mol} / \mathrm{L})$ stimulation, HT4 cells were pretreated with PMA $(0.5 \mu \mathrm{mol} / \mathrm{L})$ for $5 \mathrm{~min}$ alone or in combination with B. In experiments using Ro31-8220 (Ro, $0.5 \mu \mathrm{mol} / \mathrm{L}$ ) or GF109203X (GF, $0.5 \mu \mathrm{mol} / \mathrm{L}$ ), the drugs were applied $20 \mathrm{~min}$ before the addition of B. $n=3-4$ determinations. Mean \pm SD. ${ }^{\mathrm{b}} P<0.05 v s$ control $(100 \mu \mathrm{mol} / \mathrm{L}$ ATP only). ${ }^{\mathrm{d}} P>0.05,{ }^{\mathrm{e}} P<0.05 v s \mathrm{~B}+\mathrm{ATP}$ group.

ATP-induced $\left[\mathrm{Ca}^{2+}\right]_{\mathrm{i}}$ increase, suggesting its action at the plasma membrane, where a signal was generated and transduced into the cells. Untill now, several specific membrane proteins have been reported as the receptors that mediate the rapid actions of $\mathrm{GC}^{[15,16]}$. It is interesting to note that they are different not only in molecular weight, but also in genetic identity. Being a splice variant of the nuclear GR, one membrane receptor has been reported to have crossantigenicity with its nuclear counterpart, while others do not $^{[17]}$. The identity of the membrane target in HT4 cells is not clear and needs to be elucidated.

The potency of B-BSA in this experimental model is almost the same as that of $B$. Previous work in our lab has revealed that both $\mathrm{B}$ and $\mathrm{B}-\mathrm{BSA}$ activate $\mathrm{PKC}$ in $\mathrm{PC} 12$ cells, but the dose-dependence curve of the latter shifts rightward (ie, with lower potency ${ }^{[6]}$. The reason for the difference is also unclear.

ATP, being a normal metabolite, exists in all living cells.
In the nervous system, it is an important signaling molecule belonging to a class of fast excitatory transmitter in the brain $^{[18,19]}$. Its signaling is mediated through the metabotropic $\mathrm{P} 2 \mathrm{Y}$ and ionotropic $\mathrm{P} 2 \mathrm{X}$ receptors ${ }^{[9]}$. In our experiment, the stable ATP analog $\beta, \gamma$-meATP was shown to be a potent agonist in HT4 cells. This result strongly implies actions at P2X receptors. Modulation of $\mathrm{P} 2 \mathrm{X}$ purinoceptor-mediated $\mathrm{Ca}^{2+}$ responses by protein kinases has been well investigat$\mathrm{ed}^{[10,20-22]}$. In PC12 cells, for example, ATP-induced $\mathrm{Ca}^{2+}$ influx through $\mathrm{P} 2 \mathrm{X}$ receptors is inhibited when $\mathrm{PKC}$ activity is enhanced ${ }^{[10]}$.

It has been reported that PKA is involved in the GC rapid, nongenomic actions in many cell models ${ }^{[2]}$. It is interesting to note that the models are all pituitary-originated, such as rat pituitary cells in culture ${ }^{[23]}$, cichlid fish pituitary in vitro ${ }^{[24]}$, and mouse corticotroph tumor cell line AtT20 ${ }^{[25]}$. In contrast, studies on rat brain synaptosomes, rat hippocampal neurons, PC12 cells, and glial cell lines reveal an alternative PKC pathway ${ }^{[2,26]}$. This prompted us to speculate that the protein kinases involved in GC rapid action could be predicted by cell type ${ }^{[2]}$. However, the present data we found in HT4 cells, a mouse hippocampus-derived cell line, show that such generalization is premature and open to further consideration.

\section{Acknowledgment}

We are grateful to Dr Zhuan ZHOU (Institute of Neuroscience, Chinese Academy of Sciences) for providing us the local superfusion apparatus from which our experiments greatly benefited.

\section{References}

1 Zakon $\mathrm{H}$. The effects of steroid hormones on electrical activity of excitable cells. Trends Neurosci 1998; 21: 202-7.

2 Chen YZ, Qiu J. Pleiotropic signaling pathways in rapid, nongenomic action of glucocorticoid. Mol Cell Biol Res Commun 1999; 2: 145-9.

3 Watson CS, Gametchu B. Membrane-initiated steroid actions and the protein that mediate them. Proc Soc Exp Biol Med 1999; 220: 9-19.

4 Morimoto B, Koshland D Jr. Excitatory amino acid uptake and $N$ methyl- $D$-aspartate-mediated secretion in a neural cell line. Proc Natl Acad Sci USA 1990; 87: 3518-21.

5 Han JZ, Lin W, Chen YZ. Evoked intracellular $\mathrm{Ca}^{2+}$ elevations in HT4 neuroblastoma cells. Neuroreport 2002; 13: 1089-94.

6 Qiu J, Lou LG, Huang XY, Lou SJ, Pei G, Chen YZ. Nongenomic mechanisms of glucocorticoid inhibition of nicotine-induced calcium influx in PC12 cells: involvement of protein kinase C. Endocrinology 1998; 139: 5103-8.

7 Lou SJ, Chen YZ. The rapid inhibitory effect of glucocorticoid on cytosolic free $\mathrm{Ca}^{2+}$ increment induced by high extracellular $\mathrm{K}^{+}$and its underlying mechanism in PC12 cells. Biochem Biophys Res Commun 1998; 244: 403-7.

8 Grynkiewicz G, Poenie M, Tsien RY. A new generation of $\mathrm{Ca}^{2+}$ indi- 
cators with greatly improved fluorescence properties. J Biol Chem 1985; 260: 3440-50.

9 Ralevic V, Burnstock G. Receptors for purines and pyrimidines. Pharmacol Rev 1998; 50: 413-92.

10 Park TJ, Song SK, Kim KT. $\mathrm{A}_{2 \mathrm{~A}}$ adenosine receptors inhibit ATPinduced $\mathrm{Ca}^{2+}$ influx in $\mathrm{PC} 12$ cells by involving protein kinase A. J Neurochem 1997; 68: 2177-85.

11 Giniatullin R, Khiroug L, Talantova M, Nistri A. Fading and rebound of currents induced by ATP in PC12 cells. Br J Pharmacol 1996; 119: 1045-53.

12 Yeh KY. Corticosterone concentrations in the serum and milk of lactating rats parallel changes after induced stress. Endocrinology 1984; 15: 1364-70.

13 Blackmore P, Lattanzio G. Cell surface localization of a novel nongenomic progesterone receptor on the head of human sperm. Biochem Biophys Res Commun 1991; 181: 743-60.

14 Ramirez VD, Zheng J. Membrane sex-steroid receptors in the brain. Front Neuroendocrinol 1996; 17: 402-39.

15 Gametchu B. Glucocorticoid receptor-like antigen in lymphoma cell membranes: correlation to cell lysis. Science 1987; 236: 456-61.

16 Orchinik M, Murray TF, Moore FL. A corticosteroid receptor in neuronal membranes. Science 1991; 252: 1848-51.

17 Diba F, Watson CS, Gametchu B. 5'UTR sequences of the glucocorticoid receptor $1 \mathrm{~A}$ transcript encode a peptide associated with translational regulation of the glucocorticoid receptor. J Cell Biochem 2001; 81: 149-61.

18 Edwards FA, Gibb AJ, Colquhoun D. ATP receptor mediated synap- tic currents in the central nervous system. Nature 1992; 359: 144-6.

19 Nieber K, Poelchen W, Illes P. Role of ATP in fast excitatory synaptic potentials in locus coeruleus neurons of the rat. Br J Pharmacol 1997; 122: 423-30.

20 Chen C, Bobbin RP. P2X receptors in cochlear Deiters' cells. Br J Pharmacol 1998; 124: 337-44.

21 Boue-Grabot E, Archambault V, Seguela P. A protein kinase C site highly conserved in P2X subunits controls the desensitization kinetics of P2X(2) ATP-gated channels. J Biol Chem 2000; 275: 10190-5.

22 Seguela P, Haghighi A, Soghomonian JJ, Cooper E. A novel neuronal P2X ATP receptor ion channel with widespread distribution in the brain. J Neurosci 1996; 16: 448-55.

23 Rotsztejn W, Dussaillant M, Nobou F, Rosselin G. Rapid glucocorticoid inhibition of vasoactive intestinal peptide induced cyclic AMP accumulation and prolactin release in rat pituitary cells in culture. Proc Natl Acad Sci USA 1981; 78: 7584-8.

24 Borski RJ, Helms L, Richman N, Grau EG. Cortisol rapidly reduces prolactin release and cAMP and ${ }^{45} \mathrm{Ca}^{2+}$ accumulation in the cichlid fish pituitary in vitro. Proc Natl Acad Sci USA 1991; 88: 2758-62.

25 Iwasaki Y, Aoki Y, Katahira M, Oiso Y, Saito H. Non-genomic mechanisms of glucocorticoid inhibition of adrenocorticotropin secretion: possible involvement of GTP-binding protein. Biochem Biophys Res Commun 1997; 235: 295-9.

26 Han JZ, Lin W, Lou SJ, Qiu J, Chen YZ. A rapid, nongenomic action of glucocorticoids in rat B103 neuroblastoma cells. Biochim Biophys Acta 2002; 1591: 21-7. 